\title{
Evaluation of time courses of agreement between minutely obtained transcutaneous blood gas data and the gold standard arterial data from spontaneously breathing Asian adults, and various subgroup analyses
}

Akira Umeda ${ }^{{ }^{*}}$ (D), Masahiro Ishizaka ${ }^{2}$, Masamichi Tasaki ${ }^{2}$, Tateki Yamane ${ }^{1}$, Taiji Watanabe ${ }^{1}$, Yasushi Inoue $^{1}$, Taichi Mochizuki ${ }^{1}$, Yasumasa Okada ${ }^{3}$ and Sarah Kesler ${ }^{4}$

\begin{abstract}
Background: Usual clinical practice for arterial blood gas analysis (BGA) in conscious patients involves a one-time arterial puncture to be performed after a resting period of 20-30 min. The aim of this study was to evaluate the use of transcutaneous BGA for estimating this gold standard arterial BGA.

Methods: Spontaneously breathing Asian adults (healthy volunteers and respiratory patients) were enrolled $(n=295)$. Transcutaneous $\mathrm{PO}_{2}\left(\mathrm{PtcO}_{2}\right)$ and $\mathrm{PCO}_{2}\left(\mathrm{PtcCO}_{2}\right)$ were monitored using a transcutaneous monitor (TCM4, Radiometer Medical AsP, Denmark) with sensors placed on the chest, forearm, earlobe or forehead. Transcutaneous BGA at 1-min intervals was compared with arterial BGA at 30 min. Reasonable steps to find severe hypercapnia with $\mathrm{PaCO}_{2}>50$ mmHg were evaluated.
\end{abstract}

Results: Sensors on the chest and forearm were equally preferred and used because of small biases $(n=272)$. The average $\mathrm{PCO}_{2}$ bias was close to $0 \mathrm{mmHg}$ at $4 \mathrm{~min}$, and was almost constant (4-5 $\mathrm{mmHg}$ ) with $\mathrm{PtcCO}_{2}$ being higher than $\mathrm{PaCO}_{2}$ at $\geq 8 \mathrm{~min}$. The limit of agreement for $\mathrm{PCO}_{2}$ narrowed over time: $\pm 13.6 \mathrm{mmHg}$ at $4 \mathrm{~min}, \pm 7.5 \mathrm{mmHg}$ at 12-13 min, and $\pm 6.3 \mathrm{mmHg}$ at $30 \mathrm{~min}$. The limit of agreement for $\mathrm{PO}_{2}$ also narrowed over time $( \pm 23.1 \mathrm{mmHg}$ at 30 min). Subgroup analyses showed that the $\mathrm{PaCO}_{2}$ and $\mathrm{PaO}_{2}$ levels, gender, and younger age significantly affected the biases. All hypercapnia subjects with $\mathrm{PaCO}_{2}>50 \mathrm{mmHg}(n=13)$ showed $\mathrm{PtcCO}_{2} \geq 50 \mathrm{mmHg}$ for until $12 \mathrm{~min}$.

(Continued on next page)

\footnotetext{
* Correspondence: umeda@iuhw.ac.jp

$\mathrm{AU}$ presented part of the data at the $56^{\text {th }}$ annual meeting of Japanese Respiratory Society (Apr 8, 2016. Kyoto), and at the $114^{\text {th }}$ annual meeting of Japanese Society of Internal Medicine (Apr 15, 2017. Tokyo).

'Departments of Internal Medicine, International University of Health and Welfare (IUHW) Shioya Hospital, Tomita 77, Yaita-City, Tochigi 329-2145, Japan

Full list of author information is available at the end of the article
}

(C) The Author(s). 2020 Open Access This article is licensed under a Creative Commons Attribution 4.0 International License, which permits use, sharing, adaptation, distribution and reproduction in any medium or format, as long as you give appropriate credit to the original author(s) and the source, provide a link to the Creative Commons licence, and indicate if changes were made. The images or other third party material in this article are included in the article's Creative Commons licence, unless indicated otherwise in a credit line to the material. If material is not included in the article's Creative Commons licence and your intended use is not permitted by statutory regulation or exceeds the permitted use, you will need to obtain permission directly from the copyright holder. To view a copy of this licence, visit http://creativecommons.org/licenses/by/4.0/. The Creative Commons Public Domain Dedication waiver (http://creativecommons.org/publicdomain/zero/1.0/) applies to the data made available in this article, unless otherwise stated in a credit line to the data. 
(Continued from previous page)

Conclusions: Although $\mathrm{PtcCO}_{2}$ is useful, it cannot completely replace $\mathrm{PaCO}_{2}$ because $\mathrm{PCO}_{2}$ occasionally showed large bias. On the other hand, the prediction of $\mathrm{PaO}_{2}$ using $\mathrm{PtcO}_{2}$ was unrealistic in Asian adults. PtcCO $250 \mathrm{mmHg}$ for until 12 min can be used as a screening tool for severe hypercapnia with $\mathrm{PaCO}_{2}>50 \mathrm{mmHg}$.

Keywords: Transcutaneous, Blood gas, Bland-Altman analysis, Non-invasive, Time course, Agreement, Subgroup analysis

\section{Background}

The partial pressure of blood gases can be estimated through measurement of dissolved gases that diffuse to the skin surface $[1,2]$. Measurement of transcutaneous $\mathrm{PO}_{2}\left(\mathrm{PtcO}_{2}\right)$ and $\mathrm{PCO}_{2}\left(\mathrm{PtcCO}_{2}\right)$ requires local heating of the skin, which dilates vessels and increases arterial blood supply to the skin capillary bed under the sensor, resulting in accelerated gas diffusion [3, 4]. In clinical practice, this method is widely used to assess pulmonary gas exchange function in infants and children, and in adults with acute or chronic respiratory failure [5-7]. It may also be applied to monitoring the condition of patients on mechanical ventilation and managing limb ischemia [8-10].

Although previous studies have investigated the relationship between $\mathrm{PtcCO}_{2}$ and $\mathrm{PaCO}_{2}$ over time, the time courses of transcutaneous data for the estimation of arterial blood gas analysis (BGA) are not well characterized [11-13]. Various factors may influence the time course of agreement including the response speed of the electromechanical gas measuring system, the speed of skin heating, and the time to equilibration of gases [3, 13-15]. This information would allow physicians to choose a convenient (early) time-point for transcutaneous BGA for the estimation of arterial BGA and an optimal time-point for increased accuracy.

A previous study suggested that the correlation between arterial BGA and transcutaneous BGA data via sensors on the chest is stronger than that observed via sensors on the arm; however, this report involved only anesthetized adult patients [16]. The most commonly recommended sensor location, according to the guidelines established by the American Association for $\mathrm{Re}$ spiratory Care, is the upper chest followed by the lateral side of the abdomen, chest, buttock, inside of the upper thigh, forearm, the zygomatic bone, the ear lobe, cheek, or the forehead in neonates and small pediatric patients [9]. In the beginning, we compared data obtained from sensors placed on the chest, forearm, earlobe, and forehead in spontaneously breathing adults. In the early stage of the study, we decided to use only a chest or forearm sensor (data are shown later).

Arterial blood samples are drawn with the patient being in a steady state [17]. The usual clinical practice for arterial BGA in fully conscious patients involves a single arterial puncture performed after a waiting period of 20 $30 \mathrm{~min}[17,18]$. The procedure of arterial puncture may cause pain and hyperventilation, thereby altering subsequent arterial BGA data due to respiratory alkalosis [17]. In mechanically ventilated patients, the stability after a change in $\mathrm{F}_{\mathrm{I}} \mathrm{O}_{2}$ is reached between 10 and 30 min depending on the physiological and pathophysiological conditions of the patient [19]. Therefore, in the present study, the arterial BGA data with one-time arterial puncture after a waiting (resting) period of $30 \mathrm{~min}$ in the supine position was defined as the gold standard blood gas data.

We evaluated the transcutaneous BGA data at 1-min intervals comparing the final goal of arterial BGA at $30 \mathrm{~min}$. This novel approach will answer the following questions: "From which time point are the transcutaneous BGA data meaningful?" and "How accurately are the current transcutaneous BGA data predicting arterial BGA?" In addition, the results of the subgroup analyses which may help to understand transcutaneous BGA, are shown. Finally, we discuss the most important subgroup (i.e., severe hypercapnia with $\mathrm{PaCO}_{2}>$ $50 \mathrm{mmHg}$ ) and recommend a reasonable time-saving step for the accurate diagnosis of these patients.

\section{Methods}

\section{Subjects and study procedures}

The study was approved by the Ethics Committee of the International University of Health and Welfare (IUHW, approval number 13-B-109). All subjects provided written consent prior to participating in this study. All subjects were adults, aged $\geq 20$ years. Both healthy volunteers and patients who visited the Department of Respiratory Medicine, IUHW Shioya Hospital were invited to participate in the study. Measurements were performed in the supine position at room temperature $\left(24-25^{\circ} \mathrm{C}\right)$. Transcutaneous BGA data from 1 to $30 \mathrm{~min}$ and arterial BGA data at $30 \mathrm{~min}$ were obtained, and compared through Bland-Altman analysis [20]. Monitoring of percutaneous oxygen saturation $\left(\mathrm{SpO}_{2}\right)$ with a pulse oximeter (PULSOX-C; KONICA MINOLTA, Osaka, Japan) was performed to confirm that $\mathrm{SpO}_{2}$ data from each subject were constant during the study (from sensor fixation to arterial blood sampling).

\section{Transcutaneous BGA}

$\mathrm{PtcO}_{2}$ and $\mathrm{PtcCO}_{2}$ were measured with a transcutaneous gas monitoring system (TCM4 with tcSensor 84 for 
neonatal, pediatric and adult patients; Radiometer Medical AsP, Copenhagen, Denmark), using the principles of the Clark and Severinghaus electrodes [21]. Calibration was achieved within 5-6 min. Following membrane change, the calibration required approximately $10 \mathrm{~min}$. The temperature of the skin probe was set at $44^{\circ} \mathrm{C}$, as previously recommended $[3,8,9]$. Measurements were performed in the supine position with the skin probe position on (i) the upper chest wall (left or right second intercostal space in the midclavicular line), (ii) the inside of the forearm (upper third of the inner surface of the left or the right forearm), (iii) the earlobe, or (iv) the forehead. The sensor location was randomized and the duration of measurements was $\geq 30 \mathrm{~min}$. Prior to sensor fixation, the skin and electrode were thoroughly cleaned, and an adhesive ring with two drops of contact gel was applied, according to the instructions provided by the manufacturer. Chest hair was avoided, and depilation from the thoracic skin was not necessary. After sensor fixation, $\mathrm{PtcO}_{2}$ and $\mathrm{PtcCO}_{2}$ were recorded at 1-min intervals. Prior to sensor fixation, the sensor detected the atmospheric $\mathrm{PO}_{2}$ and $\mathrm{PCO}_{2}$. The electromechanical response of the TCM4 device, as shown by breathing on the sensor measuring atmospheric $\mathrm{PO}_{2}$ and $\mathrm{PCO}_{2}$, elicited a decrease in $\mathrm{PO}_{2}$ within $5 \mathrm{~s}$ and an increase in $\mathrm{PCO}_{2}$ within $15 \mathrm{~s}$.

\section{Arterial BGA}

Arterial BGA was performed at $30 \mathrm{~min}$ after sensor fixation in the supine position. Femoral arterial blood (0.5$1.0 \mathrm{ml}$ ) was drawn with a 22-gauge needle attached to a heparinized syringe. Samples were immediately analyzed with a blood gas analyzer (Rapidlab 1265; Siemens Healthcare Diagnostics, Sudbury, United Kingdom).

\section{Subgroup analysis}

The effects of gender, age, $\mathrm{PaCO}_{2}$ level and $\mathrm{PaO}_{2}$ level on the agreement data were evaluated. The transcutaneous data obtained via the sensors on the chest or forearm were used. The subjects with a $\mathrm{PaCO}_{2}$ level within the normal range $(35-45 \mathrm{mmHg}$ ) were compared with those having different levels of hypocapnia or hypercapnia [17]. The subjects with a $\mathrm{PaO}_{2}$ level with the normal range $(80-100 \mathrm{mmHg})$ were compared with those having hypoxemia or hyperoxemia [17].

\section{Data analysis}

Data are expressed as means \pm standard deviation $(\mathrm{SD})$, unless otherwise indicated. Concordance of arterial (at $30 \mathrm{~min}$ ) and transcutaneous (between 1 and $30 \mathrm{~min}$ ) blood gas data were investigated by Bland-Altman analysis. Therefore, 30 Bland-Altman analyses were performed. Analysis of variance with Tukey's correction or unpaired t-test (two-tailed) was used for the comparison at $30 \mathrm{~min}$. The Excel Statistics software, 2010 version (Social Survey Research Information Co., Ltd., Tokyo, Japan) was used. $P<0.05$ denoted a statistically significant difference. Data were accumulated from the usual clinical practice at IUHW Shioya Hospital. When the number of subjects using chest or forearm sensor was 163 (males: 107, females: 56), $\mathrm{PtcCO}_{2}$ at $30 \mathrm{~min}$ was markedly larger than $\mathrm{PaCO}_{2}$ at $30 \mathrm{~min}\left(P=3.8 \times 10^{-42}\right)$. In the subgroup analysis, the absolute values of $\mathrm{PO}_{2}$ bias were larger in males than in females with $P=0.050$. We calculated the necessary sample size to evaluate this interesting effect of gender. The expected effect size was $4.0 \mathrm{mmHg}$ (SD: $12.1 \mathrm{mmHg}$ ); therefore, the standardized effect size was 0.33 [22]. It was considered that approximately 100 samples per group were necessary for an $80 \%$ power to detect significance at the $10 \%$ level (twosided) in a t-test. The number of subjects using a chest or forearm sensor increased to 272 (males: 168, females: 104). The $P$-value decreased to $<0.01$ and the effect of gender was confirmed (data are shown later).

\section{Results}

The tolerance of local heating for electrode attachment was good. There were no signs of skin irritation or erythema at the end of the monitoring.

\section{Study population}

A total of 295 spontaneously breathing Asian adults (184 males, 111 females; mean age: $73.6 \pm 14.5$ years), comprising 10 healthy volunteers and 285 patients with various lung diseases, were enrolled from August 2015

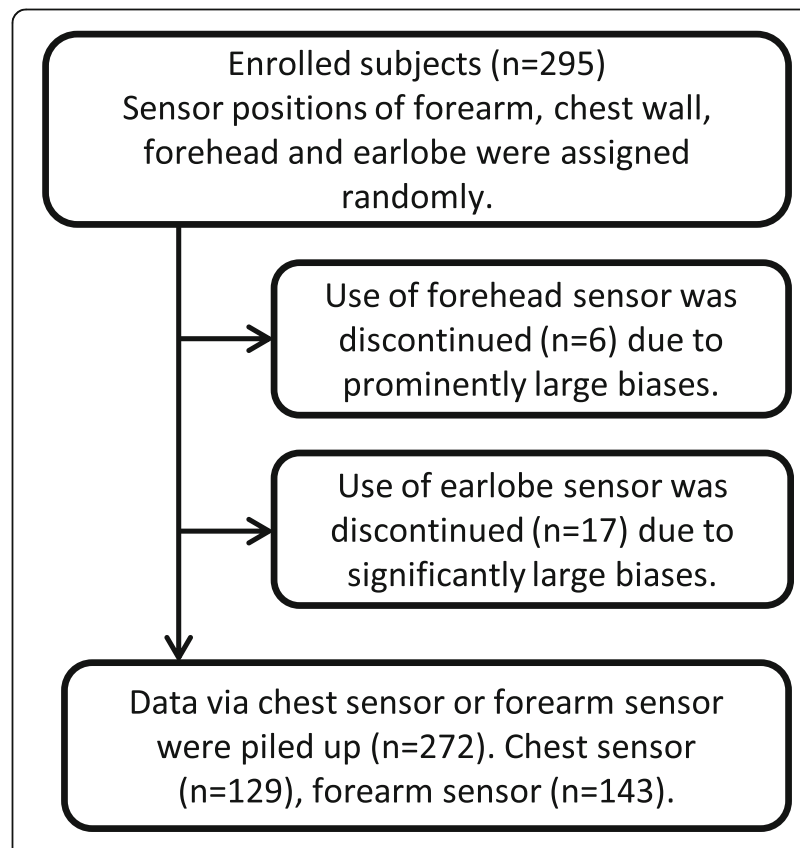

Fig. 1 Process of data collection via the chest or forearm sensors 
to August 2019. The breakdown of lung diseases is shown in Supplementary Table S1 (Additional file 1). Forty-nine subjects received oxygen therapy. These subjects were studied while receiving supplemental $\mathrm{O}_{2}$. Initially, four sensor positions were randomly used. However, shortly after the study was initiated, the use of the forehead as a sensor location was discontinued because of prominently large biases (Fig. 1). The use of the earlobe as sensor location was also discontinued because of large biases (data shown later in this article). Age, gender, body mass index and diagnosed diseases were almost equally distributed among the four groups (one group per probe; Additional file 1, Supplementary Table S1). Monitored $\mathrm{SpO}_{2}$ was stable and constant (i.e., $\leq 2 \%$ change during the $30 \mathrm{~min}$ observation period in any subject).

\section{Agreement at $30 \mathrm{~min}$}

The concordances between transcutaneous BGA and arterial BGA data at $30 \mathrm{~min}$ are shown in Fig. 2.

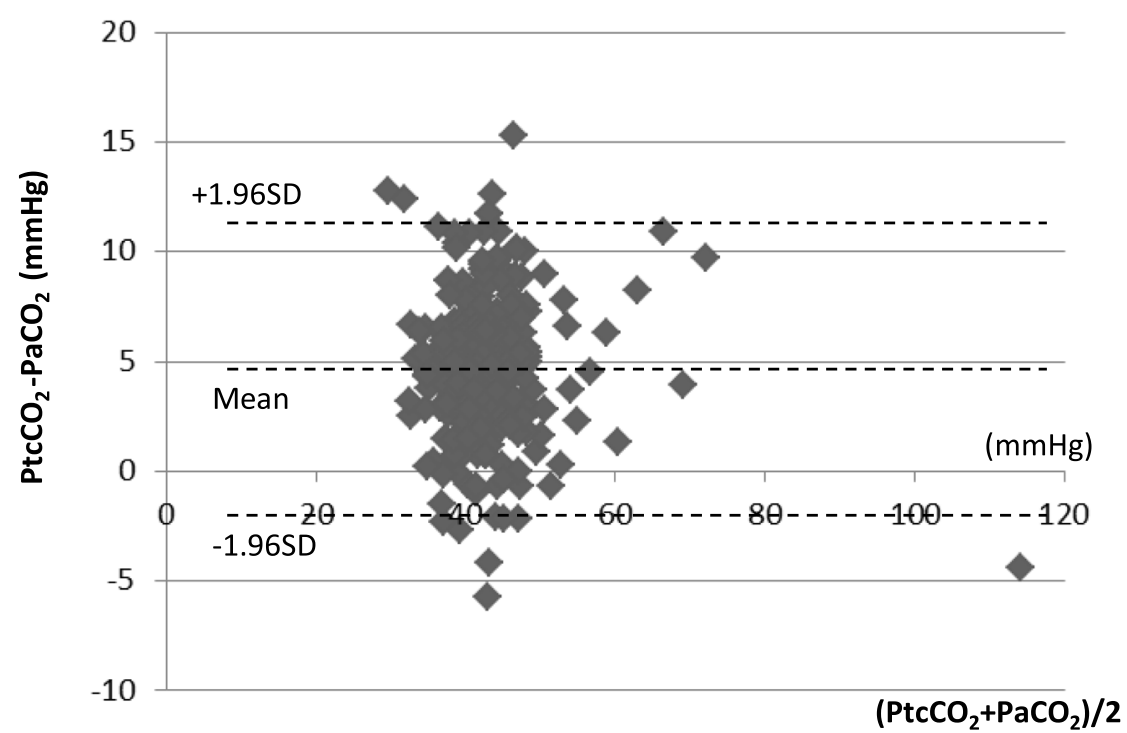

(a)

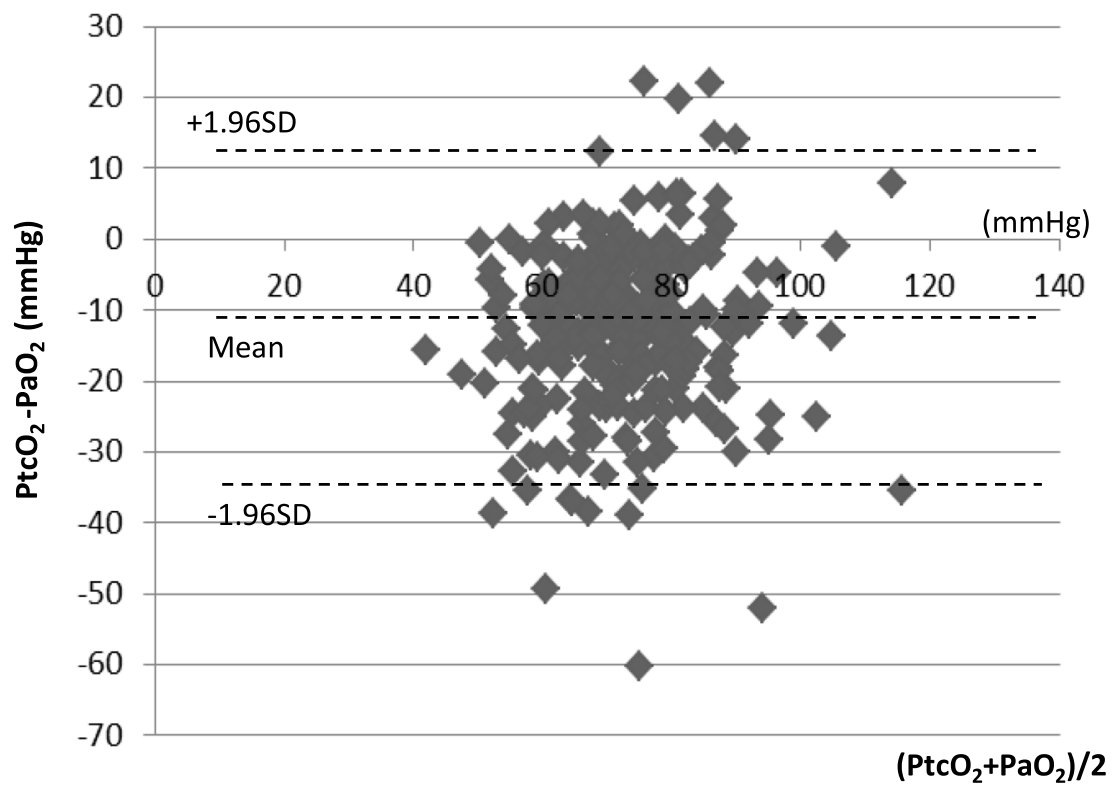

(b)

Fig. 2 Blood gas data at 30 min (transcutaneous data were obtained via the chest or forearm sensors, $n=272$ ). a Concordance between $\mathrm{PaCO}_{2}$ and $\mathrm{PtcCO}_{2}$ data at $30 \mathrm{~min}$. The bias of $\mathrm{PCO}_{2}$ was $4.7 \mathrm{mmHg}$, with $\mathrm{PtcCO}_{2}$ being higher than $\mathrm{PaCO}_{2}$ and $95 \%$ limits of agreement of $\pm 6.3 \mathrm{mmHg}$. b Concordance between $\mathrm{PaO}_{2}$ and $\mathrm{PtcO}_{2}$ data at $30 \mathrm{~min}$. The bias of $\mathrm{PO}_{2}$ was $12.2 \mathrm{mmHg}$, with $\mathrm{PaO}_{2}$ being higher than $\mathrm{PtcO}$ and $95 \%$ limits of agreement of $\pm 23.1 \mathrm{mmHg}$ 
Transcutaneous data obtained via the chest or forearm sensors were used $(n=272)$. The bias of $\mathrm{PCO}_{2}$ was 4.7 $\mathrm{mmHg}$, with $\mathrm{PtcCO}_{2}$ being higher than $\mathrm{PaCO}_{2}$, and the $95 \%$ limits of agreement were $\pm 6.3 \mathrm{mmHg}$ (Fig. 2a). The bias of $\mathrm{PO}_{2}$ was $12.2 \mathrm{mmHg}$, with $\mathrm{PaO}_{2}$ being higher than $\mathrm{PtcO}_{2}$, and the $95 \%$ limits of agreement were \pm $23.1 \mathrm{mmHg}$ (Fig. 2b).

\section{Time courses of agreement}

The time courses of the two indices used in the BlandAltman analysis (the bias and the 95\% limits of agreement) are shown in Fig. 3. This was a series of 30 Bland-Altman analyses in which we compared 1-30 min transcutaneous data with min-30 arterial BGA data. Transcutaneous data obtained via the chest or forearm sensors were used $(n=272)$. The bias of $\mathrm{PCO}_{2}$ was 0.2 $\mathrm{mmHg}$ at $4 \mathrm{~min}$ (Fig. 3a), and the $95 \%$ limits of agreement $( \pm 1.96 \mathrm{SD})$ were $\pm 13.6 \mathrm{mmHg}$ (Fig. 3b). This 1.96SD for $\mathrm{PCO}_{2}$ was initially reduced; however, it was similar to that obtained between 12 and $30 \mathrm{~min}(6.3-7.5$ $\mathrm{mmHg}$ ). At $8 \mathrm{~min}$ or later, the bias was $4.1-4.8 \mathrm{mmHg}$, with $\mathrm{PtcCO}_{2}$ being higher than $\mathrm{PaCO}_{2}$. In contrast, the absolute value of bias of $\mathrm{PO}_{2}$ was lowest (almost 0 $\mathrm{mmHg}$ ) at 1-2 min (Fig. 3c), and the 1.96SD was reduced over time, with the closest agreement observed at $30 \mathrm{~min}$ ( $\pm 23.1 \mathrm{mmHg}$ ) (Fig. 3d).

\section{Differences in agreement among four sensor locations}

The time courses of the agreement data were compared among the four sensor locations (Additional file 2, Supplementary Fig. S1). At $30 \mathrm{~min}$, the absolute values of bias obtained via the forearm and chest sensors were equivalent, and significantly lower than those obtained via the earlobe or forehead sensors for both $\mathrm{PCO}_{2}$ and $\mathrm{PO}_{2}$ (Fig. 4). At $30 \mathrm{~min}$, the absolute values of $\mathrm{PO}_{2}$ bias obtained via the earlobe sensor were significantly lower than those obtained via the forehead sensor. There was no significant difference in arterial BGA data or pulse

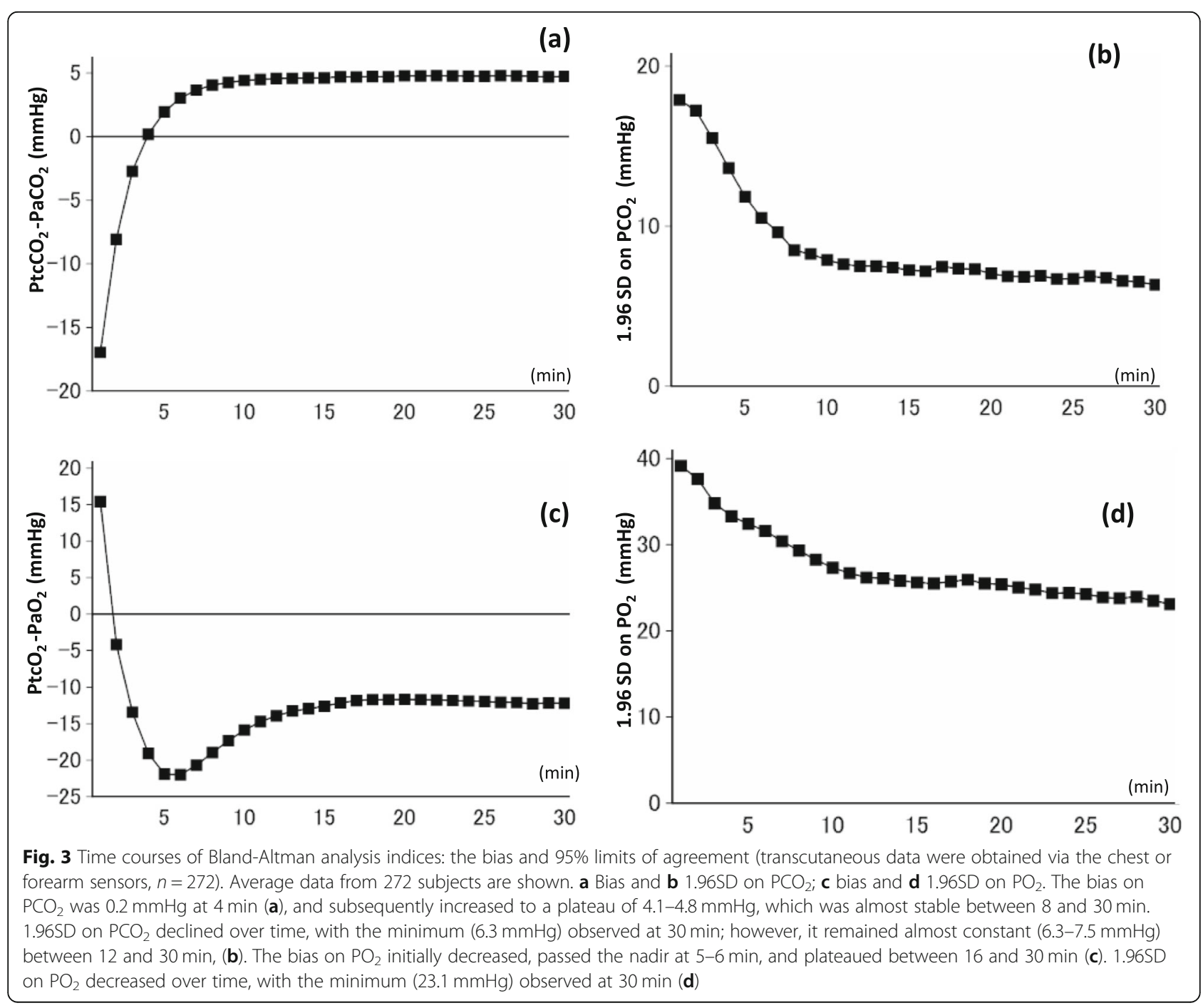


oximeter data among the four different sensor location groups (Additional file 1, Supplementary Table S2). On the other hand, $\mathrm{PtcO}_{2}$ data obtained via the earlobe or forehead sensor at $30 \mathrm{~min}$ were significantly different from those obtained via the forearm or chest sensor at $30 \mathrm{~min}$.

\section{Subgroup analyses}

\section{Effects of gender and age}

The effects of gender on the time courses were examined: male $(n=168)$, female $(n=104$, Additional file 2 , Supplementary Fig. S2). At $30 \mathrm{~min}$, the absolute values of $\mathrm{PO}_{2}$ bias in males were significantly larger than those recorded in females $(P<0.01$; Fig. $5 \mathrm{a})$. The effects of age on the time courses were examined in the following four groups: $20-39$ years $(n=11), 40-59$ years $(n=12), 60-$ 79 years $(n=138)$, and $\geq 80$ years $(n=111)$ (Additional file 2, Supplementary Fig. S3). At $30 \mathrm{~min}$, the $\mathrm{PCO}_{2}$ biases in young adults (20-39 years old) were significantly lower than those observed in the 40-59 year-old group and $\geq 80$ year-old group (both $P<0.05$; Fig. 5 b).

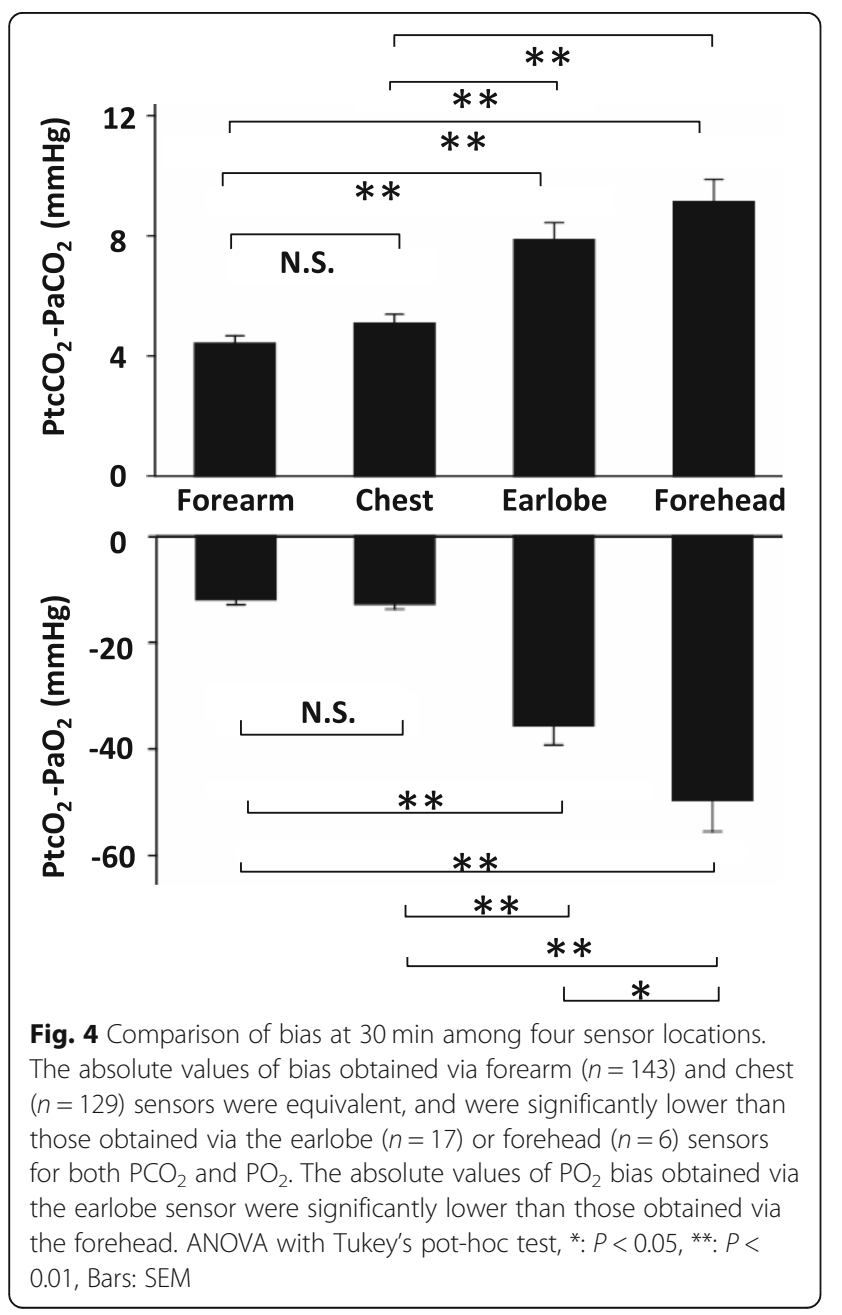

\section{Effects of $\mathrm{PaCO}_{2}$ and $\mathrm{PaO}_{2}$ levels}

The effects of hypocapnia on the time courses were examined in the following two levels of $\mathrm{PaCO}_{2}: \mathrm{PaCO}_{2}<31$ mmHg group (severe hypocapnia, $n=7$ ) and $31 \leq \mathrm{PaCO}_{2}<$ $35 \mathrm{mmHg}$ group (mild hypocapnia, $n=24$; Additional file 2, Supplementary Fig. S4). At $30 \mathrm{~min}$, the absolute values of bias in the severe hypocapnia group were higher than those noted in the normal $\mathrm{PaCO}_{2}$ group $(n=202)$ for both $\mathrm{PCO}_{2}(P<0.01)$ and $\mathrm{PO}_{2}(P<0.05$; Fig. 6a). This effect of hypocapnia on the $\mathrm{PCO}_{2}$ bias was dependent on severity. The effects of hypercapnia on the time courses were examined in the following two levels of $\mathrm{PaCO}_{2}: 45<$ $\mathrm{PaCO}_{2} \leq 50 \mathrm{mmHg}$ group (mild hypercapnia, $n=26$ ) and $>50 \mathrm{mmHg}$ group (severe hypercapnia, $n=13$; Additional file 2, Supplementary Fig. S5). At $30 \mathrm{~min}$, the $\mathrm{PCO}_{2}$ bias in the mild hypercapnia group was significantly lower than that observed in the normal $\mathrm{PaCO}_{2}$ group $(P<0.01$; Fig. 6b). The effects of the $\mathrm{PaO}_{2}$ level on the time courses were similarly examined (Additional file 2, Supplementary Fig. S6). At $30 \mathrm{~min}$, the absolute values of bias in the hypoxemia group $(n=158)$ were lower than those measured in the normal $\mathrm{PaO}_{2}$ group $(n=102)$ for both $\mathrm{PCO}_{2}(P<$ $0.05)$ and $\mathrm{PO}_{2}(P<0.01$; Fig. $6 \mathrm{c})$. At $30 \mathrm{~min}$, the absolute values of $\mathrm{PO}_{2}$ bias in the hyperoxemia group $(n=12)$ were larger than those recorded in the normal $\mathrm{PaO}_{2}$ group $(P<$ 0.05; Fig. 6c).

\section{Precise observation of subjects with hypercapnia $\mathrm{PaCO}_{2}>$ $50 \mathrm{mmHg}$}

Data and profiles of subjects with hypercapnia $\left(\mathrm{PaCO}_{2}>\right.$ $50 \mathrm{mmHg}, n=13$ ) are shown in Table 1 . Most of these subjects $(85 \%)$ were receiving $\mathrm{O}_{2}$ therapy. At $4 \mathrm{~min}$, $\mathrm{PtcCO}_{2} \geq 50 \mathrm{mmHg}$ was observed in $69 \%$ of these subjects. This ratio increased over time; at $12 \mathrm{~min}$, all these subjects showed $\mathrm{PtcCO}_{2} \geq 50 \mathrm{mmHg}$. At $13 \mathrm{~min}$, all these subjects showed $\mathrm{PtcCO}_{2} \geq 51 \mathrm{mmHg}$. Subjects with severe hypercapnia appeared to have more diseases (e.g., circulatory failure) than those with mild hypercapnia.

\section{Discussion}

By comparing the agreement between minutely obtained transcutaneous BGA data and the final answer data of arterial BGA at $30 \mathrm{~min}$, we obtained the following findings. Firstly, the sensors placed on the chest and forearm are equally preferred. Secondly, the method to predict $\mathrm{PaCO}_{2}$ at $30 \mathrm{~min}$ is to initially measure $\mathrm{PtcCO}_{2}$ at $4 \mathrm{~min}$ without bias, and observe $\mathrm{PtcCO}_{2}$ at $8 \mathrm{~min}$ or later considering a bias of $4-5 \mathrm{mmHg}$. Thirdly, although $\mathrm{PtcCO}_{2}$ is useful, it cannot completely replace the actual levels of $\mathrm{PaCO}_{2}$ due to occasional large $\mathrm{PCO}_{2}$ bias. Fourthly, the subgroup analyses showed that gender, younger age, $\mathrm{PaCO}_{2}$ levels, and $\mathrm{PaO}_{2}$ levels affected $\mathrm{PO}_{2}$ and/or $\mathrm{PCO}_{2}$ biases. Fifthly, a reasonable step to reach accurate diagnosis of $\mathrm{PaCO}_{2}>50 \mathrm{mmHg}$ using transcutaneous BGA 


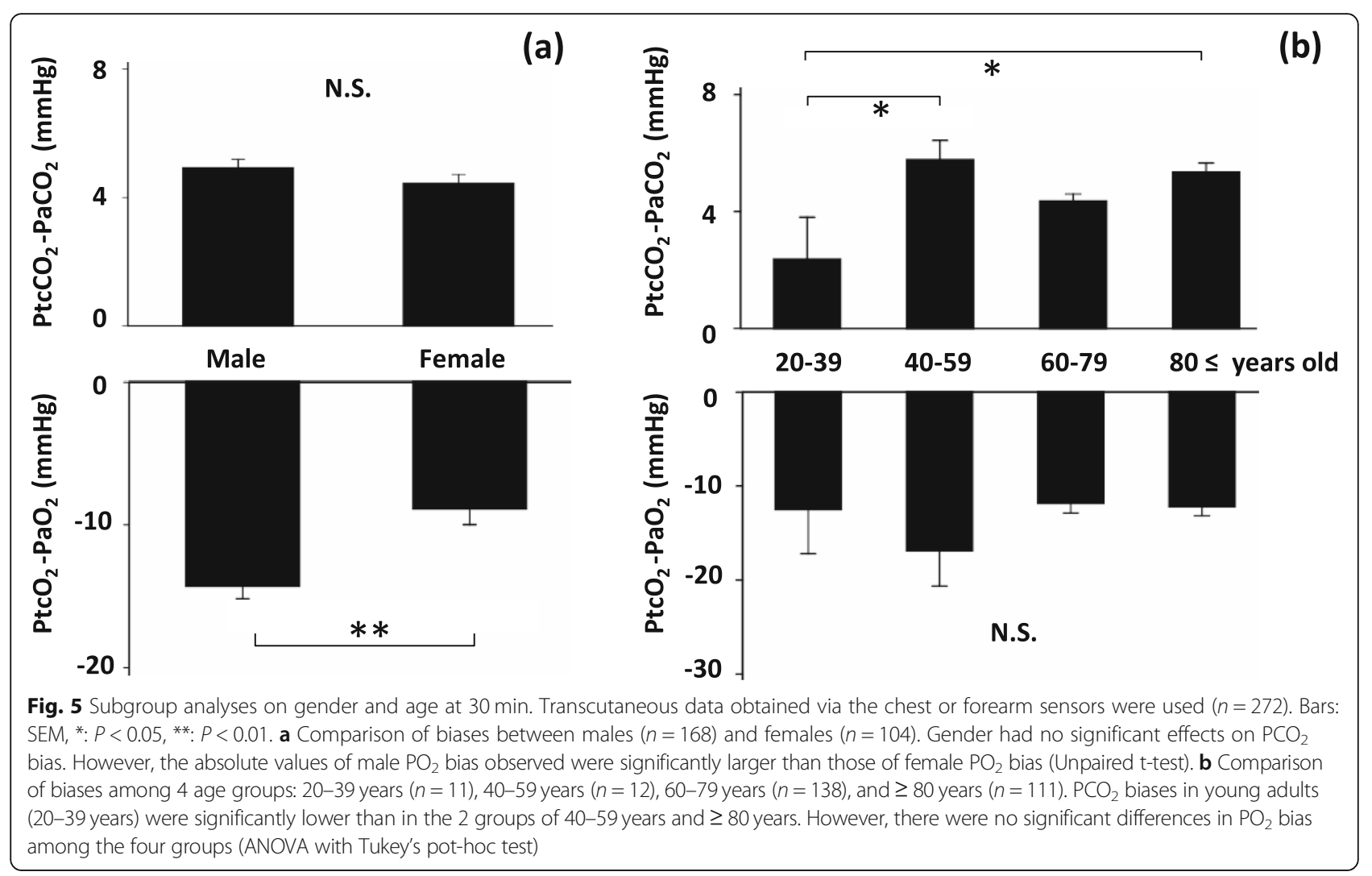

data was recommended. Finally, we showed that the prediction of $\mathrm{PaO}_{2}$ by $\mathrm{PtcO}_{2}$ was unrealistic in Asian adults.

Previously, it was reported that the 1.96SD between venous $\mathrm{PCO}_{2}$ and $\mathrm{PaCO}_{2}$ was $15.0 \mathrm{mmHg}$ [23]. Venous $\mathrm{PCO}_{2}$ is occasionally used as a surrogate with a bias of 5 $\mathrm{mmHg}$. Our approach enabled to answer the question of "From which time point are the $\mathrm{PtcCO}_{2}$ data meaningful?" The answer is "From 4 min.", because the limits of agreement between $\mathrm{PaCO}_{2}$ and $\mathrm{PtcCO}_{2}$ at 4 min or later were $\pm 13.6 \mathrm{mmHg}$ or narrower. Of note, they were narrower than the limit of agreement $( \pm 15.0 \mathrm{mmHg})$ between $\mathrm{PaCO}_{2}$ and venous $\mathrm{PCO}_{2}$. By waiting longer, we can obtain more accurate $\mathrm{PtcCO}_{2}$ data for the estimation of $\mathrm{PaCO}_{2}$. Several studies have indicated that $\mathrm{PtcCO}_{2}$ is more accurate than end-tidal $\mathrm{PCO}_{2}$ as a surrogate measure of $\mathrm{PaCO}_{2}$ [24-28]. While 1.96SD data between endtidal $\mathrm{PCO}_{2}$ and $\mathrm{PaCO}_{2}$ ranged from 6.9 to $14.4 \mathrm{mmHg}$, 1.96SD data between $\mathrm{PtcCO}_{2}$ and $\mathrm{PaCO}_{2}$ ranged from 4.6 to $10.4 \mathrm{mmHg}$. The $\mathrm{PtcCO}_{2}$ data at $12-13 \mathrm{~min}$ or later were within the acceptable clinical range of agreement for $\mathrm{PtcCO}_{2}( \pm 7.5 \mathrm{mmHg})$ recommended in the guideline of the American Association for Respiratory Care [9].

As a whole, the prediction of $\mathrm{PaCO}_{2}$ is possible. It involves initial measurement of $\mathrm{PtcCO}_{2}$ at $4 \mathrm{~min}$ without bias, and observation of $\mathrm{PtcCO}_{2}$ at 8 min or later considering a bias of $4-5 \mathrm{mmHg}$. In a steady state, $\mathrm{PtcCO}_{2}$ is higher than $\mathrm{PaCO}_{2}$ because the former is an epidermal parameter which does not exclusively reflect arterial blood, and $\mathrm{CO}_{2}$ is produced by living epidermal cells [7, 29, 30].

The 1.96SD between $\mathrm{PtcO}_{2}$ and $\mathrm{PaO}_{2}$ displayed a continual decline without an obvious plateau at $30 \mathrm{~min}$. Even the minimal limit of agreement of $\pm 24.0 \mathrm{mmHg}$ at $30 \mathrm{~min}$ is not negligible in clinical practice. Therefore, $\mathrm{PtcO}_{2}$ is not an appropriate substitute for $\mathrm{PaO}_{2}$. Kesten et al. reported that the $90 \%$ response speed of $\mathrm{PtcCO}_{2}$ in this system was approximately three times faster than that of $\mathrm{PtcO}_{2}$ [14]. The Krogh's constants of diffusion for $\mathrm{O}_{2}$ and $\mathrm{CO}_{2}$ in water and aqueous tissues may be important to understand the difference between these gases [15]. In water and aqueous tissues, the Krogh's constant of diffusion for $\mathrm{CO}_{2}$ has been reported to be 20-25 times higher than that for $\mathrm{O}_{2}$.

A change in the baseline level with time is termed "drift" [31]. The calibration was performed prior to measuring each subject according to the protocol provided by the manufacturer. The duration of the measurement was only 30-40 min per subject; therefore, the "drift" effect was considered negligible.

A few previous studies have investigated the relationship between $\mathrm{PtcCO}_{2}$ and $\mathrm{PaCO}_{2}$ over time [11-13]. Fuke et al. compared $\mathrm{PaCO}_{2}$ via an arterial catheter and $\mathrm{PtcCO}_{2}$ over time $(n=6)$, yielding evaluations of 


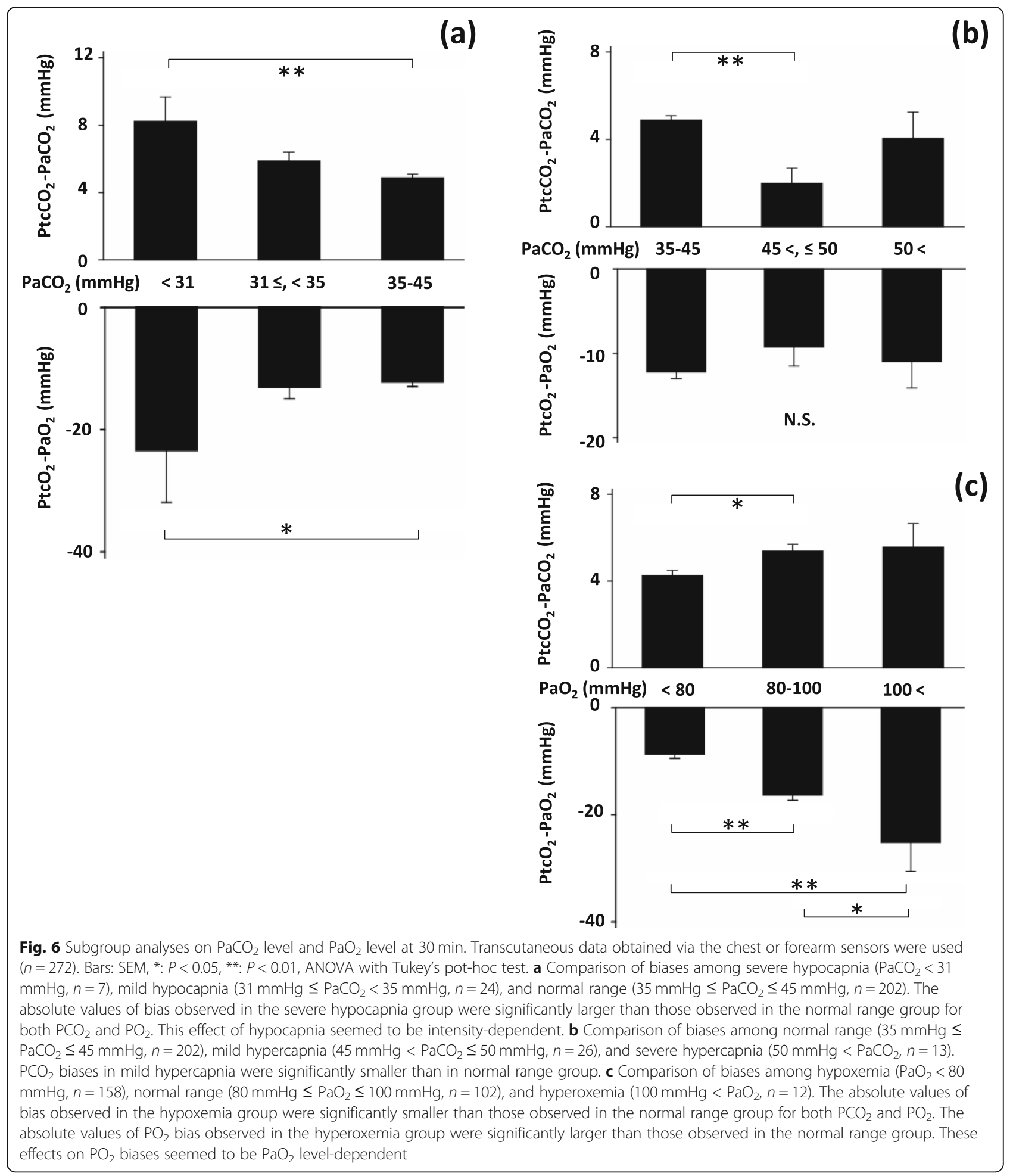

individual agreements [11]. Excellent agreement over time was shown in three subjects. Both Cuvelier et al. [12] and Storre et al. [13] compared $\mathrm{PaCO}_{2}$ via an arterial catheter and $\mathrm{PtcCO}_{2}$ over time $(n=12$ and $n=10$, respectively), demonstrating parallel changes without any description of concordance over time. The present noninvasive study without arterial catheterization is in line with the actual clinical practice for spontaneously breathing patients, and provides data from a larger sample of subjects compared with previous studies [11-13]. The subgroup analyses revealed that gender and younger age affected the biases. Further investigation is necessary 
Table 1 Data and profiles of subjects with hypercapnia $>50 \mathrm{mmHg}(n=13)$

\begin{tabular}{|c|c|c|c|c|c|c|c|c|c|c|c|c|c|c|c|c|}
\hline \multirow[t]{2}{*}{ No. } & \multirow[t]{2}{*}{ Age } & \multirow{2}{*}{$\begin{array}{l}\mathrm{O}_{2} \\
\text { therapy } \\
(\mathrm{L} / \mathrm{min})\end{array}$} & \multirow{2}{*}{$\begin{array}{l}\mathrm{PaCO}_{2} \\
(\mathrm{mmHg}) \\
\text { at } 30 \\
\text { min }\end{array}$} & \multicolumn{6}{|c|}{$\mathrm{PtcCO}_{2}(\mathrm{mmHg})$} & \multirow{2}{*}{$\begin{array}{l}\mathrm{PaO}_{2} \\
(\mathrm{mmHg}) \\
\text { at } 30 \\
\text { min }\end{array}$} & \multirow{2}{*}{$\begin{array}{l}\mathrm{PtcO}_{2} \\
(\mathrm{mmHg}) \\
\text { at } 30 \\
\text { min }\end{array}$} & \multirow[t]{2}{*}{ Characteristics } & \multirow{2}{*}{$\begin{array}{l}\text { Blood } \\
\text { pressure } \\
(\mathrm{mmHg})\end{array}$} & \multirow{2}{*}{$\begin{array}{l}\text { Body } \\
\text { temperature }\end{array}$} & \multirow{2}{*}{$\begin{array}{l}\text { Circulatory } \\
\text { failure }\end{array}$} & \\
\hline & & & & $\begin{array}{l}\text { at } \\
4 \\
\min \end{array}$ & $\begin{array}{l}\text { at } \\
10 \\
\min \end{array}$ & $\begin{array}{l}\text { at } \\
11 \\
\min \end{array}$ & $\begin{array}{l}\text { at } \\
12 \\
\min \end{array}$ & $\begin{array}{l}\text { at } \\
13 \\
\min \end{array}$ & $\begin{array}{l}\text { at } \\
30 \\
\min \end{array}$ & & & & & & & \\
\hline 1 & 76 & 2 (nasal) & 50.4 & 53 & 54 & 55 & 56 & 56 & 57 & 111.6 & 98 & $\mathrm{ACO}$ & $130 / 78$ & Normal (?) & - & - \\
\hline 2 & 82 & 3 (nasal) & 51.7 & $\underline{42}$ & $\underline{49}$ & 50 & 50 & 51 & 51 & 93.3 & 58 & $\begin{array}{l}\text { ACO, } \\
\text { pneumonia }\end{array}$ & $119 / 53$ & $35.3^{\circ} \mathrm{C}$ & - & - \\
\hline 3 & 84 & $\begin{array}{l}1.5 \\
\text { (nasal) }\end{array}$ & 52.3 & 51 & 57 & 57 & 57 & 56 & 56 & 77.3 & 75 & $\mathrm{ACO}$ & $160 / 75$ & Normal (?) & - & - \\
\hline 4 & 81 & 1 (nasal) & 52.7 & 52 & 55 & 55 & 54 & 54 & 53 & 79 & 53 & COPD (E), ILD & $128 / 59$ & Normal (?) & - & - \\
\hline 5 & 62 & $\begin{array}{l}\text { Room } \\
\text { air }\end{array}$ & 53.7 & 46 & 55 & 56 & 56 & 56 & 56 & 55 & 55 & $\mathrm{OHS}$ & $139 / 75$ & Normal (?) & - & - \\
\hline 6 & 65 & 3 (nasal) & 54.5 & $\underline{40}$ & 55 & 56 & 56 & 57 & 59 & 60.7 & 60 & $\mathrm{OHS}, \mathrm{HF}$ & $112 / 59$ & $36.2^{\circ} \mathrm{C}$ & + & + \\
\hline 7 & 89 & $\begin{array}{l}4 \text { (face } \\
\text { mask) }\end{array}$ & 55.7 & $\underline{33}$ & $\underline{49}$ & $\underline{49}$ & 51 & 52 & 62 & 50.5 & 50 & COPD (E) & $126 / 83$ & Normal (?) & - & - \\
\hline 8 & 88 & $\begin{array}{l}\text { Room } \\
\text { air }\end{array}$ & 58.8 & 59 & 66 & 66 & 67 & 67 & 67 & 80.7 & 72 & $\begin{array}{l}\text { COPD (E), HF, } \\
\text { ILD }\end{array}$ & $81 / 40$ & Normal (?) & + & \pm \\
\hline 9 & 79 & $\begin{array}{l}1.5 \\
\text { (nasal) }\end{array}$ & 59.7 & 54 & 62 & 62 & 62 & 61 & 61 & 79.8 & 76 & COPD (E) & $135 / 88$ & Normal (?) & - & - \\
\hline 10 & 85 & $\begin{array}{l}6 \text { (face } \\
\text { mask) }\end{array}$ & 61.1 & 61 & 71 & 71 & 68 & 67 & 72 & 87.9 & 64 & $\begin{array}{l}\text { OHS, airway } \\
\text { infection }\end{array}$ & $139 / 73$ & $37.3^{\circ} \mathrm{C}$ & Suspected & - \\
\hline 11 & 81 & $\begin{array}{l}1.25 \\
\text { (nasal) }\end{array}$ & 67.1 & 57 & 72 & 72 & 72 & 71 & 71 & 49.7 & 34 & COPD (E) & $119 / 81$ & Normal (?) & Suspected & \pm \\
\hline 12 & 70 & $\begin{array}{l}3 \text { (face } \\
\text { mask) }\end{array}$ & 67.3 & 57 & 80 & 81 & 81 & 81 & 77 & 81 & 77 & $\mathrm{ACO}, \mathrm{HF}$ & $135 / 61$ & $36.7^{\circ} \mathrm{C}$ & + & - \\
\hline 13 & 82 & $\begin{array}{l}5 \text { (face } \\
\text { mask) }\end{array}$ & 116.4 & 50 & 88 & 91 & 92 & 92 & 112 & 74.9 & 67 & $\begin{array}{l}\text { COPD (E), } \\
\text { MOF }\end{array}$ & $90 / 45$ & $38.5^{\circ} \mathrm{C}$ & + & ++ \\
\hline
\end{tabular}

No skin eruption was seen in any subjects. It was difficult to predict hypercapnia by underlined $\mathrm{PtcCO}_{2}$ data. All hypercapnia subjects with $\mathrm{PaCO}{ }_{2}>50$ mmHg showed $\mathrm{PtcCO}_{2} \geq 50 \mathrm{mmHg}$ for until $12 \mathrm{~min}$. All the transcutaneous blood gas analysis data were obtained via chest sensor or forearm sensor. ACO Asthmachronic obstructive pulmonary disease (COPD) overlap, COPD Chronic obstructive pulmonary disease, E Emphysema, HF Heart failure, ILD Interstitial lung disease, MOF Multiple organ failure, OHS Obesity hypoventilation syndrome

to confirm this observation. The absolute values of biases (for both $\mathrm{PCO}_{2}$ and $\mathrm{PO}_{2}$ ) were larger in the $\mathrm{PaCO}_{2}<31 \mathrm{mmHg}$ group than in the normal group. Arterial vasoconstriction by hyperventilation may be involved in this phenomenon [23]. If $\mathrm{PaCO}_{2}$ is low, the $\mathrm{PCO}_{2}$ bias may increase and underestimation of hyperventilation might occur. However, Bendjelid et al. reported that the $\mathrm{PaCO}_{2}$ level did not affect the $\mathrm{PCO}_{2}$ bias $(n=55$, Caucasians $85 \%)$ [32]. The absolute values of biases (for both $\mathrm{PCO}_{2}$ and $\mathrm{PO}_{2}$ ) were smaller in the hypoxemia group than in the normal group. Hypoxic vasodilation may be involved in this phenomenon [33].

Another limitation of the study is that arterial BGA was performed only at $30 \mathrm{~min}$. However, it is worth performing Bland-Altman analysis for the comparison of the single time point arterial BGA data with the minutely obtained transcutaneous data. All gas data were collected during a short period (30-40 min) in the steady state, which was validated by observations that $\mathrm{SpO}_{2}$ data were almost constant in each subject from the sensor fixation to the arterial blood sampling procedure. The effect of changing body position (e.g., from sitting to supine position) on $\mathrm{PaCO}_{2}$ has been reported to be smaller than that exerted on $\mathrm{PaO}_{2}[34,35]$. Bland and Altman compared data from two different peak flow meters which cannot be performed simultaneously [20].

Correct diagnosis of severe hypercapnia with $\mathrm{PaCO}_{2}>$ $50 \mathrm{mmHg}$ is important to avoid $\mathrm{CO}_{2}$ narcosis. This technology of TCM4 with a Severinghaus electrode is useful in identifying subjects with $\mathrm{PaCO}_{2}>50 \mathrm{mmHg}$. By performing arterial BGA after detecting $\mathrm{PtcCO}_{2} \geq 50 \mathrm{mmHg}$ during an observation for $12 \mathrm{~min}, \mathrm{PaCO}_{2}>50 \mathrm{mmHg}$ can be accurately measured (without exceptions at least in our 13 subjects). We recommend this reasonable step for the efficient use of $\mathrm{PtcCO}_{2}$ data.

\section{Conclusions}

We compared the agreement between minutely obtained transcutaneous BGA data and the final answer data of arterial BGA at $30 \mathrm{~min}$. The use of sensors on the chest and forearm is equally recommended. Although $\mathrm{PtcCO}_{2}$ is useful and can be used as a screening tool for severe hypercapnia, it cannot completely replace $\mathrm{PaCO}_{2}$. On the other hand, the prediction of $\mathrm{PaO}_{2}$ by $\mathrm{PtcO}_{2}$ was 
unrealistic in Asian adults. Consideration of gender, age, $\mathrm{PaCO}_{2}$ levels, and $\mathrm{PaO}_{2}$ levels may assist in improving the accuracy of estimation. Further investigations are needed to clarify the mechanisms of these factors that influence the biases. This approach may be of potential use to better understand transcutaneous BGA.

\section{Supplementary information}

Supplementary information accompanies this paper at https://doi.org/10. 1186/s12890-020-01184-w.

Additional file 1: Supplementary Table S1. Comparison of subjects among the four groups of different sensor locations. Supplementary Table S2. Comparison of blood gas data among the four groups of different sensor locations.

Additional file 2: Supplementary Fig. S1. Comparison of the time course data among the four locations of sensors. Average data are shown. Blue line: forearm $(n=143)$, red line: chest $(n=129)$, green line: earlobe $(n=17)$, and purple line: forehead $(n=6)$. Trajectories of (a) bias and (b) 1.96SD on $\mathrm{PCO}_{2}$. Trajectories of (c) bias and (d) $1.96 \mathrm{SD}$ on $\mathrm{PO}_{2}$. (a): Compared with the forearm or chest sensors, the earlobe or forehead sensors yielded larger bias for $\mathrm{PCO}_{2}$ at 4 min or later. (b): $1.96 \mathrm{SD}$ on $\mathrm{PCO}_{2}$ was similar among the four locations. (c): The forearm and chest sensors showed almost the same time course of bias for $\mathrm{PO}_{2}$. The earlobe sensor yielded larger absolute values of bias, whereas the forehead sensor yielded much larger absolute values of bias. (d): 1.96SD of the forehead sensor was larger than that of the forearm or chest sensors.

Supplementary Fig. S2. Comparison of the time course data (males vs. females, $n=272$ ). Transcutaneous data obtained via the chest or forearm sensors were used. Average data are shown. Blue line: males $(n=168)$, red line: females $(n=104)$. Trajectories of $(\mathbf{a})$ bias and $(\mathbf{b}) 1.96 \mathrm{SD}$ on $\mathrm{PCO}_{2}$ Trajectories of (c) bias and (d) $1.96 \mathrm{SD}$ on $\mathrm{PO}_{2}$. $\mathrm{PCO}_{2}$ bias was similar between the two groups (a). The $1.96 \mathrm{SD}$ of females on $\mathrm{PCO}_{2}$ was slightly lower than male (b). The absolute values of female $\mathrm{PO}_{2}$ bias was lower than that of males (c). 1.96SD on $\mathrm{PO}_{2}$ was not affected by gender (d). Supplementary Fig. S3. Comparison of the time course data (among four age groups, $n=272$ ). Transcutaneous data obtained via the chest or forearm sensors were used. Average data are shown. Blue line: 20-39 years $(n=11)$, red line: $40-59$ years $(n=12)$, green line: $60-79$ years ( $n=$ 138), purple line: $\geq 80$ ( $n=111)$. Trajectories of (a) bias and (b) 1.96SD on $\mathrm{PCO}_{2}$. Trajectories of $(\mathbf{c})$ bias and (d) $1.96 \mathrm{SD}$ on $\mathrm{PO}_{2}$. Crossing the 0 line at approximately $5 \mathrm{~min}$ (later than in the other three groups), $\mathrm{PCO}_{2}$ biases in young adults (20-39years) was slightly lower than those of the other three groups (a). The 1.96SD of young adults (20-39 years) on $\mathrm{PCO}_{2}$ was slightly higher than that of the other three groups at 21 min or later (b). The absolute values of $\mathrm{PO}_{2}$ bias in 40-59 years group seemed a little larger than those of the other three groups at 13 min or later. (c). The $1.96 \mathrm{SD}$ of young adults (20-39 years) on $\mathrm{PO}_{2}$ was slightly higher than that of the other three groups at $11 \mathrm{~min}$ or later (d). Supplementary Fig. S4. Comparison of the time course data to evaluate effects of hypocapnia. Transcutaneous data obtained via the chest or forearm sensors were used. Average data are shown. Blue line: severe hypocapnia $\left(\mathrm{PaCO}_{2}<31 \mathrm{mmHg}, n=7\right)$, red line: mild hypocapnia $(31 \mathrm{mmHg} \leq$ $\left.\mathrm{PaCO}_{2}<35 \mathrm{mmHg}, n=24\right)$, green line: normal range $(35 \mathrm{mmHg} \leq$ $\mathrm{PaCO}_{2} \leq 45 \mathrm{mmHg}, n=202$ ). Trajectories of (a) bias and (b) 1.96SD on $\mathrm{PCO}_{2}$. Trajectories of (c) bias and (d) $1.96 \mathrm{SD}$ on $\mathrm{PO}_{2}$. Crossing the 0 line at 2-3 min (earlier than in the other two groups), $\mathrm{PCO}_{2}$ biases in severe hypocapnia group was larger than those of the other two groups (a). This effect of hypocapnia seemed to be severity-dependent at 9 min or later. The 1.96SD of severe hypocapnia group was higher than that of the other two groups $(\mathbf{b}, \mathbf{d})$. The absolute values of $\mathrm{PO}_{2}$ bias in severe hypocapnia group were larger than those of the other two groups at 6 min or later. (c). Supplementary Fig. S5. Comparison of the time course data to evaluate effects of hypercapnia. Transcutaneous data obtained via the chest or forearm sensors were used. Average data are shown. Blue line: normal range $\left(35 \mathrm{mmHg} \leq \mathrm{PaCO}_{2} \leq 45 \mathrm{mmHg}, n=202\right)$, red line: mild hypercapnia ( $45 \mathrm{mmHg}<\mathrm{PaCO}_{2} \leq 50 \mathrm{mmHg}, n=26$ ), green line: severe hypercapnia $\left(50 \mathrm{mmHg}<\mathrm{PaCO}_{2}, n=13\right.$ ). Trajectories of (a) bias and (b) 1.96SD on $\mathrm{PCO}_{2}$. Trajectories of (c) bias and (d) 1.96SD on $\mathrm{PO}_{2}$. Crossing the 0 line at about 6 min (later than normal range group), $\mathrm{PCO}_{2}$ biases in mild hypocapnia group were smaller than those of normal range group (a). This delay of crossing the 0 line seemed to be severity-dependent. The 1.96SD of severe hypercapnia group on $\mathrm{PCO}_{2}$ was higher than that of the other two groups (b). The absolute values of $\mathrm{PO}_{2}$ bias in mild hypercapnia group were smaller than those of normal range group at 2 min or later (c). 1.96SD on $\mathrm{PO}_{2}$ seemed to be about the same among the three groups (d). Supplementary Fig. S6. Comparison of the time course data to evaluate effects of $\mathrm{PaO}_{2}$ levels. Transcutaneous data obtained via the chest or forearm sensors were used. Average data are shown. Blue line: hypoxemia $\left(\mathrm{PaO}_{2}<80 \mathrm{mmHg}, n=158\right)$, red line: normal range $\left(80 \mathrm{mmHg} \leq \mathrm{PaO}_{2} \leq 100 \mathrm{mmHg}, n=102\right)$, green line: hyperoxemia $\left(100 \mathrm{mmHg}<\mathrm{PaO}_{2}, n=12\right)$. Trajectories of (a) bias and (b) 1.96SD on $\mathrm{PCO}_{2}$. Trajectories of $(\mathbf{c})$ bias and $(\mathbf{d}) 1.96 \mathrm{SD}$ on $\mathrm{PO}_{2} . \mathrm{PCO}_{2}$ biases in hypoxemia group were smaller than those of the other two groups (a). The 1.96SD on $\mathrm{PCO}_{2}$ seemed to be about the same among the three groups (b). The absolute values of $\mathrm{PO}_{2}$ bias in hypoxemia group were smaller than those of normal range group (c). The absolute values of $\mathrm{PO}_{2}$ bias in hyperoxemia group were larger than those of normal range group (c). The 1.96SD of hyperoxemia group on $\mathrm{PO}_{2}$ was higher than that of the other two groups $(\mathbf{d})$.

\section{Abbreviations}

AARC: American Association for Respiratory Care; ACO: Asthma-chronic obstructive pulmonary disease overlap; ANOVA: Analysis of variance; BGA: Blood gas analysis; COPD: Chronic obstructive pulmonary disease; IUHW: International University of Health and Welfare; $\mathrm{PtCCO}_{2}$ : Transcutaneous $\mathrm{PCO}_{2}$; $\mathrm{PtCO}_{2}$ : Transcutaneous $\mathrm{PO}_{2}$; SD: Standard deviation;

$\mathrm{SpO}_{2}$ : Percutaneous oxygen saturation

\section{Acknowledgements}

We thank all the participants of this study. We especially thank Ms. Rena Ishizaki for assisting with the data reduction work.

\section{Authors' contributions}

$\mathrm{AU}$ : conceived the idea, involved in patient management, data collection and statistical analysis, drafted and revised the manuscript for intellectual content. Ml: involved in patient management and data collection, revised the manuscript for intellectual content. MT: involved in data collection, revised the manuscript. TY, TW, YI, TM and SK revised the manuscript for intellectual content. YO: involved in statistical analysis, revised the manuscript for intellectual content. All authors have read and approved the manuscript.

\section{Funding}

This work was partly supported by IUHW Shioya Hospital.

\section{Availability of data and materials}

The datasets used in this study are available from the corresponding author upon reasonable request.

\section{Ethics approval and consent to participate}

The project was approved by the Ethics Committee of the International University of Health and Welfare (IUHW, approval number 13-B-109). All subjects provided written consent before participating in this study.

\section{Consent for publication}

Not applicable.

\section{Competing interests}

The authors have no potential conflicts of interest.

\section{Author details}

${ }^{1}$ Departments of Internal Medicine, International University of Health and Welfare (IUHW) Shioya Hospital, Tomita 77, Yaita-City, Tochigi 329-2145, Japan. ${ }^{2}$ Departments of Rehabilitation, International University of Health and Welfare (IUHW) Shioya Hospital, Yaita-City, Japan. ${ }^{3}$ Department of Internal Medicine, National Hospital Organization Murayama Medical Center, 
Musashimurayama-City, Japan. ${ }^{4}$ Intensive Care Unit, University of Minnesota, Minneapolis, MN, USA.

Received: 7 March 2018 Accepted: 13 May 2020

Published online: 29 May 2020

\section{References}

1. Huch R, Huch A, Albani M, Gabriel M, Schulte FJ, Wolf H, et al. Transcutaneous $\mathrm{PO}_{2}$ monitoring in routine management of infants and children with cardiorespiratory problems. Pediatrics. 1976;57(5):681-90.

2. Huch A, Seiler D, Meinzer K, Huch R, Galster H, Lübbers DW. Transcutaneous $\mathrm{PCO}_{2}$ measurement with a miniaturised electrode. Lancet. 1977;1 (8019):982-3.

3. Lucey JF. Clinical uses of transcutaneous oxygen monitoring. Adv Pediatr. 1981;28:27-56

4. Wimberley PD, Pedersen KG, Thode J, Fogh-Andersen N, Sørensen AM, Siggaard-Andersen $\mathrm{O}$. Transcutaneous and capillary $\mathrm{pCO}_{2}$ and $\mathrm{pO}_{2}$ measurements in healthy adults. Clin Chem. 1983;29(8):1471-3.

5. Rüdiger M, Töpfer $K$, Hammer H, Schmalisch G, Wauer RR. A survey of transcutaneous blood gas monitoring among European neonatal intensive care units. BMC Pediatr. 2005:5:30.

6. Delerme S, Montout V, Goulet H, Arhan A, Le Saché F, Devilliers C, et al. Concordance between transcutaneous and arterial measurements of carbon dioxide in an ED. Am J Emerg Med. 2012;30(9):1872-6.

7. Stieglitz S, Matthes S, Priegnitz C, Hagmeyer L, Randerath W. Comparison of transcutaneous and capillary measurement of $\mathrm{PCO}_{2}$ in hypercapnic subjects. Respir Care. 2016:61(1):98-105.

8. Nishiyama T, Nakamura S, Yamashita K. Effects of the electrode temperature of a new monitor, TCM4, on the measurement of transcutaneous oxygen and carbon dioxide tension. J Anesth. 2006:20(4):331-4.

9. Restrepo RD, Hirst KR, Wittnebel L, Wettstein R. AARC clinical practice guideline: transcutaneous monitoring of carbon dioxide and oxygen: 2012 Respir Care. 2012;57(11):1955-62.

10. Ruangsetakit C, Chinsakchai K, Mahawongkajit $P$, Wongwanit C, Mutirangura P. Transcutaneous oxygen tension: a useful predictor of ulcer healing in critical limb ischaemia. J Wound Care. 2010;19(5):202-6.

11. Fuke S, Miyamoto K, Ohira H, Ohira M, Odajima N, Nishimura M. Evaluation of transcutaneous $\mathrm{CO}_{2}$ responses following acute changes in $\mathrm{PaCO}_{2}$ in healthy subjects. Respirology. 2009;14(3):436-42.

12. Cuvelier A, Grigoriu B, Morano LC, Muir JF. Limitation of transcutaneous carbon dioxide measurements for assessing long-term mechanical ventilation. Chest. 2005;127(5):1744-8.

13. Storre JH, Steurer B, Kabitz HJ, Dreher M, Windisch W. Transcutaneous PCO2 monitoring during initiation of noninvasive ventilation. Chest. 2007;132(6): 1810-6.

14. Kesten S, Chapman KR, Rebuck AS. Response characteristics of a dual transcutaneous oxygen/carbon dioxide monitoring system. Chest. 1991; 99(5):1211-5.

15. Dejours P. Oxygen and carbon dioxide exchanges by diffusion. In: Principles of comparative respiratory physiology. 2nd ed. Amsterdam: Elsevier/NorthHolland Biomedical Press; 1981. p. 63-74.

16. Nishiyama T, Nakamura S, Yamashita K. Comparison of the transcutaneous oxygen and carbon dioxide tension in different electrode locations during general anaesthesia. Eur J Anaesthesiol. 2006;23(12):1049-54.

17. Malley WJ. Arterial blood gases. In: Clinical blood gases: Assessment and Intervention. 2nd ed. St. Louis: Elsevier Saunders; 2005. p. 3-34.

18. American Association for Respiratory Care. AARC clinical practice guideline. Sampling for arterial blood gas analysis. Respir Care. 1992;37(8):913-7.

19. Sasse SA, Jaffe MB, Chen PA, Voelker KG, Mahutte CK. Arterial oxygenation time after an $\mathrm{FlO} 2$ increase in mechanically ventilated patients. Am J Respir Crit Care Med. 1995;152(1):148-52.

20. Bland JM, Altman DG. Statistical methods for assessing agreement between two methods of clinical measurement. Lancet. 1986;1(8476):307-10.

21. Malley WJ. Blood gas electrodes and quality assurance. In: Clinical blood gases: Assessment and Intervention. 2nd ed. St. Louis: Elsevier Saunders; 2005. p. 82-113.

22. Hulley SB, Cummings SR, Browner WS, Grady DG, Newman TB. Designing clinical research. 4th ed. Philadelphia: Lippincott Williams \& Wilkins, a Wolters Kluwer business; 2013.

23. Umeda A, Kawasaki K, Abe T, Watanabe M, Ishizaka A, Okada Y. Hyperventilation and finger exercise increase venous-arterial $\mathrm{PCO}_{2}$ and $\mathrm{pH}$ differences. Am J Emerg Med. 2008;26(9):975-80.
24. Aliwalas LL, Noble L, Nesbitt K, Fallah S, Shah V, Shah PS. Agreement of carbon dioxide levels measured by arterial, transcutaneous and end tidal methods in preterm infants $<$ or $=28$ weeks gestation. J Perinatol. 2005; 25(1):26-9.

25. Tobias JD, Meyer DJ. Noninvasive monitoring of carbon dioxide during respiratory failure in toddlers and infants: end-tidal versus transcutaneous carbon dioxide. Anesth Analg. 1997;85(1):55-8.

26. Oshibuchi M, Cho S, Hara T, Tomiyasu S, Makita T, Sumikawa K. A comparative evaluation of transcutaneous and end-tidal measurements of $\mathrm{CO}_{2}$ in thoracic anesthesia. Anesth Analg. 2003;97(3):776-9.

27. Tingay DG, Stewart MJ, Morley CJ. Monitoring of end tidal carbon dioxide and transcutaneous carbon dioxide during neonatal transport. Arch Dis Child Fetal Neonatal Ed. 2005;90(6):F523-6.

28. Hirabayashi M, Fujiwara C, Ohtani N, Kagawa S, Kamide M. Transcutaneous $\mathrm{PCO}_{2}$ monitors are more accurate than end-tidal $\mathrm{PCO}_{2}$ monitors. J Anesth 2009;23(2):198-202.

29. Severinghaus JW, Bradley AF, Stafford MJ. Transcutaneous $\mathrm{PCO}_{2}$ electrode design with internal silver heat path. Birth Defects Orig Artic Ser. 1979;15(4): 265-70.

30. Severinghaus JW, Stafford M, Thunstrom AM. Estimation of skin metabolism and blood flow with tcPO $\mathrm{PO}_{2}$ and $\mathrm{tc} \mathrm{PO}_{2}$ electrodes by cuff occlusion of the circulation. Acta Anaesthesiol Scand Suppl. 1978;68:9-15.

31. Malley WJ. Noninvasive blood gas monitoring. In: Clinical blood gases: Assessment and Intervention. 2nd ed. St. Louis: Elsevier Saunders; 2005. p. 387-418.

32. Bendjelid K, Schütz N, Stotz M, Gerard I, Suter PM, Romand JA. Transcutaneous PCO2 monitoring in critically ill adults: clinical evaluation of a new sensor. Crit Care Med. 2005;33(10):2203-6.

33. Kulandavelu S, Balkan W, Hare JM. Regulation of oxygen delivery to the body via hypoxic vasodilation. Proc Natl Acad Sci U S A. 2015;112(20):6254-

34. Sandoval J, Alvarado P, Martínez-Guerra ML, Gómez A, Palomar A, Meza S, et al. Effect of body position changes on pulmonary gas exchange in Eisenmenger's syndrome. Am J Respir Crit Care Med. 1999;159(4 Pt 1):10703.

35. Hardie JA, Mørkve O, Ellingsen I. Effect of body position on arterial oxygen tension in the elderly. Respiration. 2002:69(2):123-8.

\section{Publisher's Note}

Springer Nature remains neutral with regard to jurisdictional claims in published maps and institutional affiliations.

Ready to submit your research? Choose BMC and benefit from:

- fast, convenient online submission

- thorough peer review by experienced researchers in your field

- rapid publication on acceptance

- support for research data, including large and complex data types

- gold Open Access which fosters wider collaboration and increased citations

- maximum visibility for your research: over $100 \mathrm{M}$ website views per year

At BMC, research is always in progress.

Learn more biomedcentral.com/submissions 